\title{
HUBUNGAN MPLS DALAM MENGURANGI KASUS BULLYING DI SEKOLAH WILAYAH JAKARTA TIMUR PROVINSI DKI JAKARTA
}

\author{
Kunaenih $^{1}$, Nadiah ${ }^{2}$ \\ ${ }^{1}$ Pendidikan Agama Islam/Fakultas Agama Islam, Universitas Islam Jakarta \\ ${ }^{2}$ Pendidikan Agama Islam/Fakultas Agama Islam, Universitas Islam Jakarta \\ *Email: kunaenih@uid.ac.id, Nadiahdiyaa@gmail.com
}

\begin{abstract}
Abstrak : Tujuan penelitian ini adalah untuk mengetahui cara mengurangi Bullying melalui MPLS di Sekolah, dan mendapatkan model pelaksanaan program MPLS yang tepat sasaran dan tepat guna. Judul penelitian ini adalah hubungan MPLS dalam mengurangi kasus Bullying di sekolah wilayah Jakarta Timur Provinsi DKI Jakarta. Permasalahan dalam penelitian ini adalah : 1) Seberapa besar pengaruh MPLS terhadap mengurangi terjadinya Bullying di sekolah wilayah Jakarta Timur Provinsi DKI Jakarta ?, 2) Bagaimana mengurangi Bullying melalui program MPLS untuk sekolah di wilayah Jakarta Timur Provinsi DKI Jakarta? Metode penelitian yang digunakan dalam penelitian ini adalah Penelitian korelasi atau korelasional. Berdasarkan hasil penelitian yang dilakukan maka kesimpulan yang dapat diambil adalah : 1) Dari 10 (Sepuluh) sekolah yang menjadi sampel dalam penelitian ini dapat disampaikan bahwa terdapat pengaruh antara MPLS terhadap Bullying di sekolah, pengaruhnya sebesar $43 \%$. Pengaruh ini dikategorikan cukup berpengaruh. 2) Cara mengurangi Bullying disekolah melalui program MPLS untuk sekolah wilayah Jakarta Timur Provinsi DKI Jakarta adalah dengan mengurangi keterlibatan peserta didik senior dalam pelaksanaan MPLS di sekolah. Karena keterlibatan peserta didik senior dalam pelaksanaan MPLS rentan terjadinya kekerasan baik itu Verbal ataupun Non Verbal.
\end{abstract}

Kata Kunci : MPLS; Kasus; Bullying 
Abstract : The purpose of this study was to find out how to reduce bullying through MPLS in schools, and to obtain a model for implementing the MPLS program that is right on target and effective. The title of this research is the relationship between MPLS in reducing cases of bullying in schools in the East Jakarta area of DKI Jakarta Province. The problems in this research are: 1) How much influence does MPLS have on reducing the occurrence of bullying in schools in the East Jakarta area of DKI Jakarta Province? 2) How to reduce bullying through the MPLS program for schools in the East Jakarta area of DKI Jakarta Province? The research method used in this research is correlation or correlational research. Based on the results of the research conducted, the conclusions that can be drawn are: 1) Of the 10 (ten) schools sampled in this study, it can be said that there is an influence between MPLS on bullying in schools, the effect is $43 \%$. This influence is categorized as quite influential. 2) How to reduce bullying in schools through the MPLS program for schools in the East Jakarta area of DKI Jakarta Province is to reduce the involvement of senior students in implementing MPLS in schools. Because the involvement of senior students in the implementation of MPLS is prone to violence, both verbal and non-verbal.

Keywords: MPLS; Case; Bullying

\section{PENDAHULUAN}

Perilaku Bullying dari waktu ke waktu terus menghantui anak-anak Indonesia. Kasus Bullying yang sering dijumpai adalah kasus senioritas atau adanya intimidasi siswa yang lebih senior terhadap adik kelasnya baik secara fisik maupun non-fisik

Kasus kekerasan di sekolah beberapa waktu ini menjadi sangat marak terjadi. Sekolah yang seyogyanya mampu menjadi tempat yang aman dan nyaman bagi siswanya untuk menuntut ilmu namun kenyataannya masih terdapat sekolah yang jauh dari gambaran tersebut. Sekolah yang seharusnya mampu menjadi rumah kedua bagi peserta didik, sehingga tujuan Pendidikan Nasional yaitu "mencerdaskan kehidupan bangsa dan mengembangkan manusia Indoensia seutuhnya, yaitu manusia yang beriman dan bertaqwa terhadap Tuhan Yang Maha Esa dan berbudi pekerti luhur, memiliki pengetahuan dan keterampilan, kesehatan jasmani dan rohani, kepribadian yang mantap dan mandiri serta rasa tanggung jawab kemasyarakatan dan kebangsaan" dapat tercapai.

Namun kenyataannya sekolah kita saat ini menjadi salah satu tempat yang kurang nyaman dan aman bagi anak-anak kita. Hal ini dapat kita lihat dari beberapa data yang penulis akan coba paparkan dari berbagai sumber. Dikutip dari oke zone tercatat ada 6 Kasus Kekerasan dan Bullying di Sekolah yang terjadi pada awal tahun 2019. 
Berikut lima kasus kekerasan dalam dunia pendidkan Tanah Air yang dirangkum Okezone, Selasa (12/2/2019): ${ }^{1}$

\section{Peserta Ospek Dipaksa Makan Makanan Encer}

Pertengahan Januari 2019, dunia maya digegerkan dengan beredarnya sebuah video yang memperlihatkan beberapa siswa dipaksa mengkonsumsi makanan encer dalam sebuah ember oleh seniornya.

Diduga para siswa tersebut tengah mengikuti masa orientasi pasukan pengibar bendera (paskibraka). Video yang beredar di media sosial itu memperlihatkan para senior memperlakukan mereka seperti binatang.

\section{Tewasnya Taruna ATKP Makassar}

Aldama Putra (19), mahasiswa ATKP Makassar mengembuskan napas terakhirnya di Rumah Sakit Sayang Rakyat Makassar, pada 5 Februari 2019.

Meninggal dengan luka lebam disekujur tubuh, Aldama diketahui menjadi korban penganiayaan oleh seniornya. Penganiayaan terjadi pada Minggu 3 Februari 2019, sekira Pukul 21.30 Wita. Aldama dianiaya karena tidak mengenakan helm saat masuk ke lingkungan kampus yang berada di Jalan Salodong, kecamatan Bringkanaya, Makassar.

\section{Murid Mem-Bully Gurunya di Gresik}

Video berdurasi 30 detik itu direkam di salah satu sekolah di Kabupaten Gerisik, Jawa Timur. Dalam video tersebut, seorang siswa sesekali mendorong bahkan mengarahkan tanganya yang terkepal ke arah sang guru. Ia juga tampak merokok di hadapan guru tersebut dan mengeluarkan kata-kata yang tidak pantas.

Melihat aksi muridnya itu, guru tersebut tidak membalas dan hanya menatap siswanya. Sementara, para siswa yang lain asyik merekam dan menertawakan. Aksi tidak sopan tersebut justru dinilai sebagai hal yang lucu.

Diantara faktor penyebab terjadinya kekerasan di sekolah adalah karena peserta didik yang tidak siap menghadapi pelajaran yang baru di sekolah yang baru. Untuk itu pada tahun 2016 Menteri Pendidikan dan Kebudayaan Anis Baswedan menggagas MPLS (Masa Pengenalan Lingkungan Sekolah) sebagai pengganti MOS ( Masa Orientasi Sekolah).

MPLS dijadikan sebagai ajang untuk melatih ketahanan mental, disiplin, dan mempererat tali persaudaraan. MPLS juga sering dipakai sebagai sarana perkenalan siswa terhadap lingkungan baru di sekolah tersebut. Baik itu perkenalan dengan sesama siswa baru, senior, guru, hingga karyawan lainnya di sekolah itu. Tak terkecuali pengenalan berbagai macam kegiatan yang ada dan rutin dilaksanakan di lingkungan sekolah.

Masa Pengenalan Lingkungan Sekolah berisi tentang tata cara pelaksanaan kegiatan yang menghilangkan stigma negatif tentang pelaksanaan masa orientasi

\footnotetext{
${ }^{1}$ Okezone, Selasa (12/2/2019): ${ }^{1}$
} 
siswa yang terjadi saat ini. Di dalam Permendikbud tersebut, tidak boleh lagi diadakan kegiatan yang berisi atau menjurus kepada perploncoan atau kegiatan lain yang merugikan peserta didik baru. Selanjutnya, yang bertanggung jawab atas terlaksananya kegiatan ini adalah kepala sekolah. Apabila ditemukan pelanggaranpelanggaran, maka sanksi yang diberikan mengacu Peraturan Menteri Pendidikan dan Kebudayaan Nomor 82 Tahun $2015^{2}$ tentang Pencegahan dan Penanggulangan Tindak Kekerasan pada Satuan Pendidikan dan peraturan perundang-undangan lainnya. Bahkan, apabila pelanggaran sangatlah berat, kepala sekolah terancam dicopot dan siswa yang melakukan didrop out dari sekolah.

Berdasarkan pengamatan tentang kondisi kekerasan yang masih ada di sekolah sampai dengan saat ini. Padahal sudah ada MPLS sebagai salah satu upaya menghentikan perpeloncoan di sekolah sudah ada sejak tahun 2016 melalui permendikbud tahun 2016 no 18. Maka, melalui penelitian ini diupayakan dapat melahirkan sebuah gagasan (model) yang dapat dikontribusikan untuk dunia pendidikan kita saat ini khususnya di Provinsi DKI Jakarta demi keamanan dan kenyamanan peserta didik kita belajar di sekolah sehingga tujuan pendidikan dapat tercapai dengan maksimal.

Menciptakan pendidikan yang sehat, dan menciptakan sekolah sebagai rumah kedua bagi peserta didik kita menjadi sekolah yang aman dan nyaman. Menjadi tempat yang dicintai, dan menjadi tempat berlindung. Dengan menganalisa implementasi program MPLS yang dilakukan, diharapkan penelitian ini dapat menghadirkan pemahaman yang baru dan tepat guna, sehingga tujuan dari program MPLS sebagai pengganti MOS dapat tercapai. Yaitu agar perpeloncoan tidak terjadi lagi di sekolah-sekolah kita.

Peneliti sebelumnya Risdiyanto Prayoga (2016) melakukan penelitian yang serupa mengenai Penerapan Kegiatan Masa Orientasi Peserta Didik (MOPD) Dalam Menyiapkan Peserta Didik Baru di Fakultas Keguruan Dan Ilmu Pendidikan Universitas Lampung Bandar Lampung. ${ }^{3}$ Dalam penelitian tersebut menunjukkan bahwa peranan kegiatan masa orientasi peserta didik (MOPD) dalam menyiapkan peserta didik baru di SMA Negeri 1 Seputih Banyak terdapat hubungan yang positif, signifikan, dan kategori keeratan sedang antara peranan kegiatan masa orientasi peserta didik dalam menyiapkan peserta didik baru, artinya semakin terprogram dan terlaksana dengan baik kegiatan masa orientasi maka sangat berperan kegiatan tersebut untuk menyiapkan peserta didik baru dalam hal mental, fisik dan akademik. Perihal ini perlu diterapkan di setiap sekolah karena peserta didik yang memiliki kesiapan mental, fisik dan akademik akan lebih mampu membentengi dirinya dari perbuatan Bullying yang akan menimpa mereka.

\footnotetext{
${ }^{2}$ mengacu Peraturan Menteri Pendidikan dan Kebudayaan Nomor 82 Tahun $2015^{2}$

3 Prayoga (2016) melakukan penelitian yang serupa mengenai Penerapan Kegiatan Masa Orientasi Peserta Didik (MOPD) Dalam Menyiapkan Peserta Didik Baru di Fakultas Keguruan Dan Ilmu Pendidikan Universitas Lampung Bandar Lampung. ${ }^{3}$
} 
Pada dasarnya, setiap peserta didik dan sekolah adalah objek penelitian yang harus dibimbing dan diarahkan untuk meninggalkan kebiasaan Bullying . Memotivasi mereka untuk memiliki semangat belajar yang tinggi dan mampu memperbaiki dirinya lebih baik lagi. Untuk itu, pelaksanaan penelitian ini menjadi penting dilakukan sehingga dapat membantu mengarahkan ke arah yang baik bagi para peserta didik. Penelitian ini dilakukan di sekolah-sekolah wilayah Jakarta Timur di Provinsi DKI Jakarta berdasarkan latar belakang yang telah penulis sampaikan.

\section{METODE}

Metode penelitian yang digunakan dalam penelitian ini adalah Penelitian korelasi atau korelasional adalah suatu penelitian untuk mengetahui hubungan dan tingkat hubungan antara dua variabel atau lebih tanpa ada upaya untuk mempengaruhi variabel tersebut sehingga tidak terdapat manipulasi variabel (Faenkel dan Wallen, 2008:328 ${ }^{4}$ ). Adanya hubungan dan tingkat variabel ini penting karena dengan mengetahui tingkat hubungan yang ada, peneliti akan dapat mengembangkannya sesuai dengan tujuan penelitian. Jenis penelitian ini biasanya melibatkan ukuran statistik/tingkat hubungan yang disebut dengan korelasi (Mc Millan dan Schumacher, dalam Syamsuddin dan Vismaia, 2009:25). ${ }^{5}$ Penelitian korelasional menggunakan instrumen untuk menentukan apakah, dan untuk tingkat apa, terdapat hubungan antara dua variabel atau lebih yang dapat dikuantitatifkan.

\section{Tempat dan Waku Penelitian}

Penelitian ini akan dilaksanakan di sekolah-sekolah di 5 Kecamatan Wilayah

Kota Jakarta Timur Provinsi DKI Jakarta. Penelitian ini dilaksanakan selama 3

Bulan terhitung sejak bulan Mei - Agustus 2019.

\section{Populasi Penelitian}

Populasi dalam penelitian ini yaitu Madrasah Aliyah Swasta (MAS), Madrasah Aliyah Negeri (MAN), Sekolah Menengah Atas Swasta (SMAS), Sekolah Menengah Atas Negeri (SMAN), Sekolah Menengah Kejuruan Swasta (SMKS) dan Sekolah menengah Kejuruan Negeri (SMKN) di Wilayah Kota Jakarta Timur Provinsi DKI Jakarta yang berjumlah 346 Sekolah.

\section{Sampel Penelitian}

Penelitian pengembangkan ini menggunakan beberapa Teknik Sampling diantaranya adalah :

1. Purposive Sampling

Purposive Sampling (Sampel Bertujuan) dari 6 Wilayah Kota administrasi di Provinsi DKI Jakarta, Peneliti menentukan Wilayah Kota

\footnotetext{
${ }^{4}$ Fraenkel, J.R dan Wellen, N.E. 2008. How to Design and Evaluate research in Education. ${ }^{4}$ ). ${ }^{5}$ (Mc Millan dan Schumacher, dalam Syamsuddin dan Vismaia, 2009:25). ${ }^{5}$
} 
Jakarta Timur menjadi sampel dalam penelitian ini. Karena, secara Geografis merupakan wilayah dengan jumlah sekolah terbanyak dari 5 wilayah lainnya.

Tabel 1 Jumlah Sekolah di Wilayah Provinsi DKI Jakarta

\begin{tabular}{|c|l|c|c|c|c|c|c|c|}
\hline \multirow{2}{*}{$\begin{array}{c}\text { N } \\
\mathrm{o}\end{array}$} & \multirow{2}{*}{$\begin{array}{l}\text { Kabupaten } \\
\text { /Kota }\end{array}$} & \multicolumn{3}{|c|}{$\begin{array}{c}\text { SMA/Sederaja } \\
\mathrm{t}\end{array}$} & \multicolumn{3}{|c|}{ SMK/Sederajat } & \multirow{2}{*}{$\begin{array}{c}\text { Tota } \\
1\end{array}$} \\
\cline { 2 - 8 } 1 & $\begin{array}{l}\text { Kepulauan } \\
\text { Seribu }\end{array}$ & 1 & 1 & 2 & 1 & 0 & 1 & 3 \\
\hline 2 & Jakarta Pusat & $\begin{array}{c}1 \\
4\end{array}$ & 49 & 63 & 14 & 46 & 60 & 123 \\
\hline 3 & Jakarta Utara & $\begin{array}{c}1 \\
9\end{array}$ & 85 & 104 & 8 & 67 & 75 & 179 \\
\hline 4 & Jakarta Barat & 2 & 111 & 134 & 9 & 109 & 118 & 252 \\
\hline 5 & $\begin{array}{l}\text { Jakarta } \\
\text { Selatan }\end{array}$ & $\begin{array}{c}3 \\
4\end{array}$ & 97 & 131 & 18 & 114 & 132 & 263 \\
\hline 6 & $\begin{array}{l}\text { Jakarta } \\
\text { Timur }\end{array}$ & 4 & 104 & 152 & 13 & 181 & 194 & 346 \\
\hline
\end{tabular}

Sumber : referensi.data.kemdikbud.go.id diakses 28 Juni 2019. 10:40

\section{Random Sampling}

Random Sampling (Pemilihan Sampel Secara Acak) digunakan untuk menentukan sekolah yang akan dituju dari 5 kecamatan diwilayah Jakarta Timur Provinsi DKI Jakarta. Teknik sampling ini juga digunakan untuk menentukan siswa yang akan menjadi sampel dari sekolah pilihan berdasarkan teknik di atas.

\section{Instrumen Penelitian}

Pada penelitian instrument utama adalah pengambil data dan instrumen uji. Instrumen yang digunakan ada dua macam. Sekala pengukuran pada instrument tersebut menggunakan Penyataan atau pernyataan tadi kemudian direspon dalam bentuk skala likert, yang diungkapkan melalui kata-kata misalnya ; setuju, sangat setuju, tidak pasti, tidak setuju, sangat tidak setuju. (Sugioyono, 2008). ${ }^{6}$

\footnotetext{
6. Sugioyono, 2008Metode Penelitian Pendidikan: Pendekatan Kuantitatif, Kualitatif dan $R n D{ }^{6}$
} 
Tabel 2 Kisi-kisi Instrumen

\begin{tabular}{|c|c|c|c|}
\hline $\mathrm{No}$ & Variabel & Definisi Operasional & Indikator \\
\hline 1 & $\begin{array}{l}\text { Masa } \\
\text { Pengenalan } \\
\text { Lingkungan } \\
\text { Sekolah } \\
\text { (MPLS) }\end{array}$ & $\begin{array}{l}\text { kegiatan pengenalan } \\
\text { bagi peserta didik } \\
\text { baru yang bersifat } \\
\text { Edukatif. Melepaskan } \\
\text { setiap kegiatan yang } \\
\text { tidak masuk akal dan } \\
\text { menyulitkan peserta } \\
\text { didik, sehingga } \\
\text { menimbulkan } \\
\text { perpeloncoan dan } \\
\text { sebagainya sebagai } \\
\text { rasa senioritas. }\end{array}$ & $\begin{array}{l}\text { 1. Mengenali potensi } \\
\text { diri } \\
\text { 2. Membantu siswa } \\
\text { baru beradaptasi } \\
\text { dengan } \\
\text { lingkungannya } \\
\text { 3. Menumbuhkan } \\
\text { motivasi, semangat, } \\
\text { dan cara belajar } \\
\text { efektif sebagai siswa } \\
\text { baru } \\
\text { 4. Mengembangkan } \\
\text { interaksi positif } \\
\text { antar siswa dan } \\
\text { warga sekolah } \\
\text { lainnya } \\
\text { 5. Menumbuhkan } \\
\text { perilaku positif } \\
\text { antara lain, } \\
\text { kejujuran, } \\
\text { kemandirian, sikap } \\
\text { saling menghargai, } \\
\text { menghormati } \\
\text { keanekaragaman dan } \\
\text { persatuan, } \\
\text { kedisiplinan, hidup } \\
\text { bersih dan sehat } \\
\text { untuk mewujudkan } \\
\text { siswa yang eiliki } \\
\text { nilai integritas, etos } \\
\text { kerja dan semangat } \\
\text { gorong royong pada } \\
\text { diri siswa }\end{array}$ \\
\hline 2 & Bullying & $\begin{array}{l}\text { segala perbuatan } \\
\text { yang dilakukan baik } \\
\text { verbal ataupun } \\
\text { Nonverbal yang } \\
\text { menimbulkan } \\
\text { ketidaknyamanan } \\
\text { bahkan sakit hati oleh }\end{array}$ & $\begin{array}{l}\text { 1. Perilaku yang } \\
\text { menyebabkan } \\
\text { seseorang merasa } \\
\text { menderita } \\
\text { 2. Dilakukan secara } \\
\text { berulang } \\
\text { 3. Dilakukan secara }\end{array}$ \\
\hline
\end{tabular}




\begin{tabular}{|l|l|lr|l|}
\hline & \multicolumn{2}{|l|}{ korban atas perbuatan } \\
individu & atau & verbal \\
kelompok & yang & Dilakukan secara \\
merasa & fisik \\
berkuasa & lebih & 5. Menyakiti secara \\
psikologis \\
& & 6. Menilbulkan trauma \\
& & $\begin{array}{l}\text { 7. Korban tidak } \\
\text { berdaya }\end{array}$ \\
& & 8. Perilaku menggertak \\
\hline
\end{tabular}

\section{Teknik Pengambilan Data}

Berbagai jenis instrumen dapat digunakan untuk mengukur dan mengumpulkan data masing-masing variabel, seperti angket, tes, pedoman interview dan pedoman observasi, tentunya disesuaikan dengan kebutuhan. Data yang dikumpulkan dengan instrumen-instrumen tersebut harus dalam bentuk angka. Dalam penelitian korelasional, pengukuran variabel dapat dilakukan dalam waktu yang relatif sama. Instrument yang dibuat akan diberikan kepada responden yaitu peserta didik yang mengikuti MPLS pada tahun pelajaran 2018-2019.

\section{Teknik Analisis Data}

Pada dasarnya, analisis dalam penelitian korelasional dilakukan dengan cara mengkorelasikan hasil pengukuran suatu variabel dengan hasil pengukuran variabel lain.

Sesuai dengan data yang diperoleh, maka penulis akan menganalisis dengan metode deskriptif kuantitatif. Metode ini menggunakan rumus Dalam penelitian ini penulis menggunakan pendekatan metode deskriptif korelasional analitik, yaitu metode penelitian yang bertujuan untuk menemukan ada tidaknya pengaruh dan apabila ada, berapa besarnya pengaruh serta berarti atau tidaknya pengaruh itu. Metode ini menggunakan tahapan sebagai berikut :

1. Mencari angka korelasi, dengan rumus:

$$
r_{x y}=\frac{N \Sigma X Y-(\Sigma X)(\Sigma Y)}{\sqrt{\left[N \Sigma X^{2}-(\Sigma X)^{2}\right]\left[N \Sigma Y^{2}-\left(\Sigma Y^{2}\right)\right]}}
$$

$\begin{aligned} \mathrm{r}_{\mathrm{xy}} & =\text { Angka indeks korelasi”" }{ } \text { "product moment } \\ \mathrm{N} & =\text { Number of Case } \\ \Sigma \mathrm{XY} & =\text { Jumlah hasil penelitian antara skor X (Metode Role } \\ & \text { Playing) dan skor Y (Hasil Belajar Fiqh) } \\ \Sigma \mathrm{X} & =\text { Jumlah seluruh skor X (Metode Role Playing) } \\ \Sigma \mathrm{Y} & =\text { Jumlah seluruh skor Y (Hasil Belajar Fiqh) }\end{aligned}$

(Furchan :2011; 179) 
2. Memberikan interpretasi terhadap $r_{x y}$ yaitu:

a) Memberikan interpretasi sederhana dengan cara mencocokan hasil perhitungan dengan indeks korelasi"r"product moment seperti dibawah ini :

Tabel 3 Indeks Korelasi Product Moment

\begin{tabular}{|l|l|}
\hline $\begin{array}{c}\text { Besarnya"r"Product } \\
\text { Moment (rxy) }\end{array}$ & \multicolumn{1}{c|}{ Interpretasi } \\
\hline $0,00-0,20$ & $\begin{array}{l}\text { Antara variabel X dan variabel Y memang } \\
\text { terdapat korelasi, akan tetapi korelasi itu } \\
\text { lemah atau sangat rendah sehingga korelasi } \\
\text { itu diabaikan (dianggap tidak ada korelasi } \\
\text { antara variabel X dan variabel Y). }\end{array}$ \\
\hline $0,20-0,40$ & $\begin{array}{l}\text { Antara variabel X dan variabel Y terdapat } \\
\text { korelasi yang lemah atau rendah }\end{array}$ \\
\hline $0,40-0,70$ & $\begin{array}{l}\text { Antara variabel X dan variabel Y terdapat } \\
\text { korelasi yang sedang atau cukup }\end{array}$ \\
\hline $0,70-0,90$ & $\begin{array}{l}\text { Antara variabel X dan variabel Y terdapat } \\
\text { korelasi yang kuat atau tinggi }\end{array}$ \\
\hline $0,90-1,00$ & $\begin{array}{l}\text { Antara variabel X dan variabel Y terdapat } \\
\text { korelasi yang sangat tinggi }\end{array}$ \\
\hline
\end{tabular}

Metode penelitian menjelaskan rancangan kegiatan, ruang lingkup atau objek, bahan dan alat utama, tempat, sumber data, teknik pengumpulan data, definisi operasional variabel penelitian, dan teknik analisis [4,5].

\section{HASIL DAN PEMBAHASAN}

\section{A. Temuan Data}

Di sekolah wilayah Jakarta Timur peneliti telan melakukan Observasi dan menyebarkan instrument penelitian, berikut peneliti sampaikan nama-nama sekolah dan jumlah sampelnya :

Table 4.1

Jumlah Sampel Peserta Didik dari Beberapa Sekolah

\begin{tabular}{|c|l|c|}
\hline No & \multicolumn{1}{|c|}{ Nama Sekolah } & $\begin{array}{c}\text { Jumlah Peserta } \\
\text { Didik }\end{array}$ \\
\hline 1 & SMK Nurul Huda & 10 Orang \\
\hline 2 & SMK Al-Hadiriyah & 10 Orang \\
\hline 3 & SMK Cawang Jakarta & 10 Orang \\
\hline 4 & SMA Muhammadiyah 12 & 10 Orang \\
\hline 5 & SMK L' Pina & 10 Orang \\
\hline 6 & SMK Budi Murni 1 & 10 Orang \\
\hline 7 & SMK Kemala Bhayangkari & 10 Orang \\
\hline 8 & SMK Muara Indonesia & 10 Orang \\
\hline
\end{tabular}




\begin{tabular}{|c|l|c|}
\hline 9 & SMK PGRI 39 & 10 Orang \\
\hline 10 & SMK Nurul Iman & 10 Orang \\
\hline \multicolumn{2}{|c|}{ Jumlah } & 100 Orang \\
\hline
\end{tabular}

Sekolah-sekolah yang menjadi sekolah sampel adalah sekolah yang pasti telah melaksanakan MPLS dan responden juga telah mengikuti MPLS selama 3 hari, yaitu hari Senin s.d Rabu Tanggal 15 s.d 17 Juli 2019 berdasarkan kalender akademik dan surat edaran pelaksanaan PLS (Terlampir).

Selanjutnya setiap peserta didik yang menjadi sampel menjawab beberapa pernyataan yang ada dalam instrument, yaitu mengenai Pelaksanaan MPLS di sekolah mereka dan keadaan mereka dalam mengikuti kegiatan pembelajaran yang berkaitan dengan Bullying. Dalam memberikan bobot penilaian peneliti menggunakan pengukuran Skala Likert.

\section{B. Pembahasan}

Jumlah responden dari 10 (Sepuluh) sekolah di wilayah Jakarta Timur dengan jumlah 100 (Seratus) Orang, mereka semua telah mengikuti Masa Pengenalan Lingkungan Sekolah (MPLS). Berdasarkan data yang telah dikumpulkan dan dianalisis secara cermat dan teliti, kemudian melakukan pembahasan lebih lanjut terhadap data yang ditemui dari masing-masing sekolah.

FORMULA

$=\frac{\sum \mathrm{XY}-\frac{\sum \mathrm{X} \sum \mathrm{Y}}{\mathrm{n}}}{\sqrt{\left(\left(\sum \mathrm{X}^{2}\right)-\frac{\left(\sum \mathrm{X}\right)^{2}}{\mathrm{n}}\right)\left(\left(\sum \mathrm{Y}^{2}\right)-\frac{\left(\sum \mathrm{Y}\right)^{2}}{\mathrm{n}}\right)}}$

Data Perhitungan Yang Dibutuhkan :

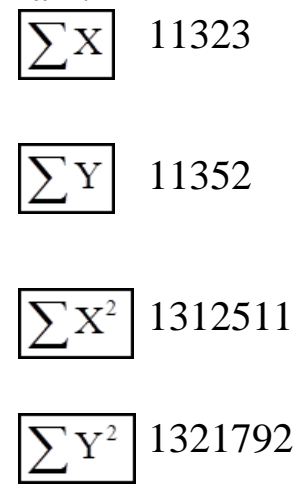




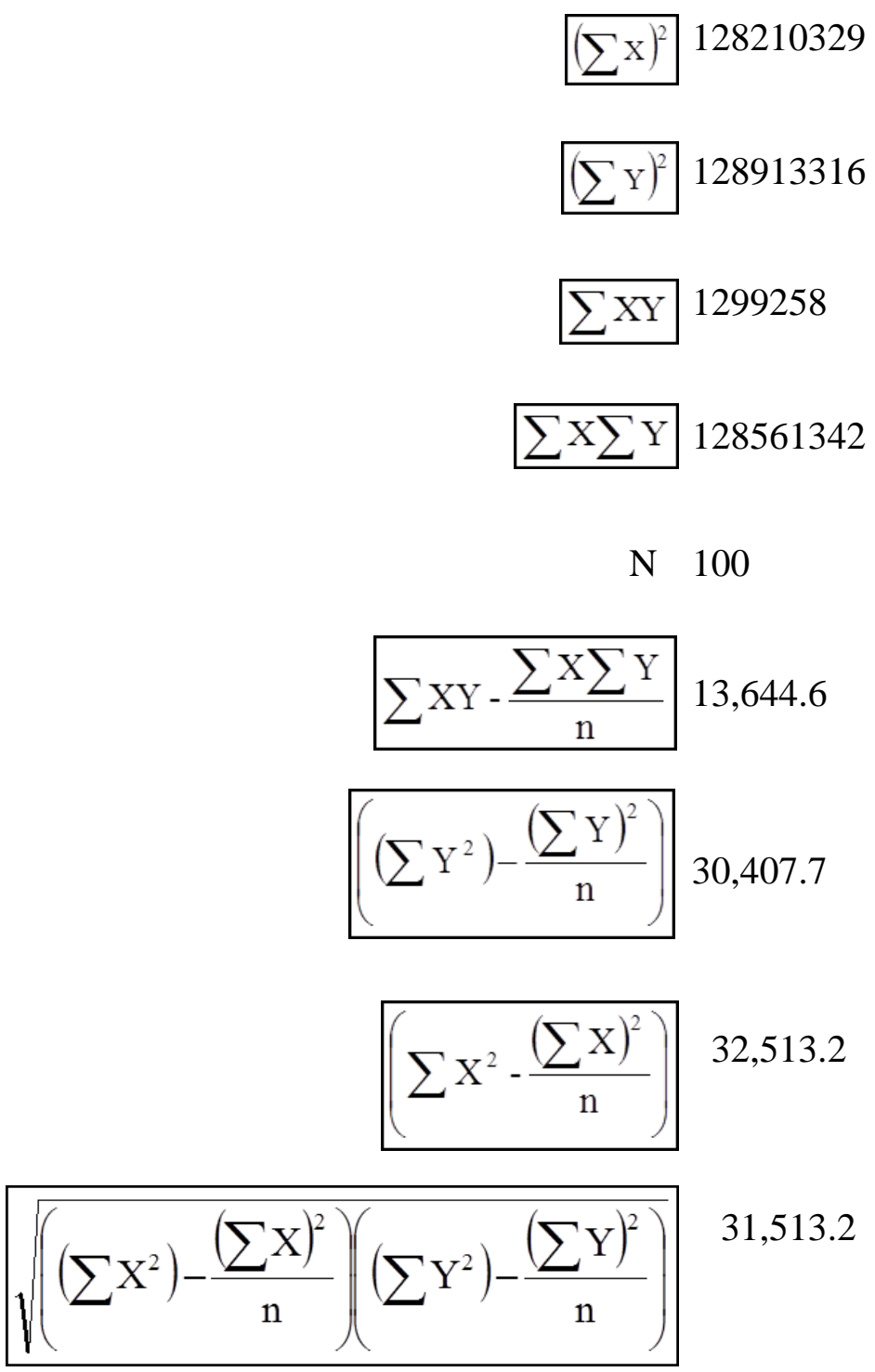

Hasil Hitung Manual

0.43

Perhitungan Dengan EXCEL CORREL

0.43

Instrument yang diberikan kepada responden telah melalui proses Uji Validitas (Terampir). Selanjutnya berdasarkan hasil analisis butir instrument yang dijawab oleh responden. Maka, peneliti mendapatkan hasil penelitian yaitu sebesar 0,43 yang berarti bahwa korelasinya adalah Cukup (Sedang). 
Jadi, dapat dipahami bahwa pengaruh MPLS dalam mengurangi Bullying di sekolah adalah sebesar $43 \%$ sedangkan $57 \%$ sisanya dipengaruhi oleh faktor lain.

Tujuan MPLS dalam mengurangi Bullying di Sekolah sudah menunjukan hasilnya terbukti bahwa MPLS memiliki pengaruh yang cukup. Sehingga, jika pelaksanaan MPLS dapat terus di maksimalkan maka dapat dipastikan bullying di sekolah dapat terus berkurang.

Selanjutnya peneliti melakukan analisa terhadap butir-butir instrument yang dijawab oleh responden. Untuk variable $X$ (MPLS), dalam pelaksanaannya ternyata sudah cukup sesuai dengan yang diharapkan. Dibuktikan dengan tingginya jumlah hasil akhir pada pernyataan dalam instrument pada butir 10, 25, 26 dan 30, buyi dari pernyataan dalam instrument tersebut adalah :

1. Butir instrument No. 6 : kegiatan PLS disekolah ini dilaksanakan secara Gratis

2. Butir instrument No. 8 : saya mendapat materi tentang bahaya Pornografi

3. Butir instrument No. 9 : saya semakin percaya diri untuk belajar setelah mengikuti PLS

4. Butir instrument No. 10 : kegiatan PLS kemarin sangat bermanfaat bagi saya

5. Butir instrument No. 14 : saya tidak mendapat tugas yang mempersulit saya saat PLS

6. Butir instrument No. 16 : kami sudah mengetahui peraturah sekolah dari soisalisasi saat PLS

7. Butir instrument No. 29 : Guru-guru saya di sekolah sangat baik

Dari beberapa instrument tersebut di atas. Butir teratas menunjukan bahwa kegiatan MPLS dilaksanakan secara Gratis. Secara umum dapat dilihat bahwa peserta didik menikmati masa-masa MPLS dan merasakan manfaat dari pelaksanaan kegiatan ini. Dan ini sesuai dengan Permendikbud No. 8 Tahun 2016.

Selanjutnya, peneliti melakukan analisis butir instrument untuk variable Y (Bullying) dalam pelaksanaannya sudah sesuai dengan silabus pelaksanaan PLS . Dibuktikan dengan tingginya jumlah hasil akhir pada pernyataan Positif yang ada dalam instrument. Yaitu ada pada butir 12, 17. 20 dan 29, buyi dari pernyataan dalam instrument tersebut adalah :

1. Butir instrument No. 12 : saya tidak takut bertanya pada guru saat belajar

2. Butir instrument No. 17 : Saya memiliki hubungan baik dengan kakak kelas saya

3. Butir instrument No. 20 : Saya memiliki motifasi yang sangat baik untuk belajar

4. Butir instrument No. 29 : Guru-guru saya membuat saya nyaman di sekolah 
Dari beberapa instrument tersebut di atas. Butir teratas menunjukan bahwa peserta didik sudah memiliki rasa percaya diri yang baik untuk mengikuti ptoses belajar di sekolah.

Sehingga dapat dilihat bahwa korelasi antara MPLS dalam mengurangi bullying telah nampak secara signifikan. Dalam arti korelasi yang cukup (Sedang).

\section{KESIMPULAN}

Berdasarkan hasil penelitian yang dilakukan maka kesimpulan yang dapat diambil adalah :

1. Dari 10 (Sepuluh) sekolah yang menjadi sampel dalam penelitian ini dapat disampaikan bahwa terdapat pengaruh antara MPLS terhadap Bullying di sekolah, pengaruhnya sebesar $43 \%$. Pengaruh ini dikategorikan cukup berpengaruh.

2. Cara mengurangi Bullying disekolah melalui program MPLS untuk sekolah wilayah Jakarta Timur Provinsi DKI Jakarta adalah dengan mengurangi keterlibatan peserta didik senior dalam pelaksanaan MPLS di sekolah. Karena keterlibatan peserta didik senior dalam pelaksanaan MPLS rentan terjadinya kekerasan baik itu Verbal ataupun Non Verbal.

\section{Saran}

Selanjutnya saran yang dapat peneliti sampaikan berdasarkan kesimpulan di atas adalah :

1. Pelaksanaan program PLS semestinya dapat dilaksanakan sesuai dengan silabus dan ketentuan yang ada dalam Permendikbud No. 18 Tahun 2016.

2. Berdasarkan butir angket pada variable $X$ nomor 12 bahwaq masih ada keterlibatan kakak kelas yang cukup dominan dalam pelaksanaan PLS. Maka, peneliti menyarankan agar mengurangi keterlibatan peserta didik senior.

3. Buat design kegiatan semenarik mungkin sehingga pesetra didik tidak merasakan bosan dalam mengikuti kegiatan PLS di sekolah.

4. Hasil penelitian ini perlu disampaikan kepada pihak terkait sehingga dapat disikapi secara baik. Untuk mengurangi dampak Bullying di sekolah.

Melihat bahwa PLS memiliki pengaruh yang cukup dalam mengurangi kasus Bullying di Sekolah. Maka, Perlu adanya penelitian lanjutan untuk wilayah-wilayah di luar Provinsi DKI Jakarta sebagai bahan perbandingan, sehingga selanjutnya kita bisa mendapatkan model design program PLS yang terbaik. 


\section{REFERENSI}

Aprilia Eunike. 2018. Hubungan Bullying dengan kepercayaan Diri Pada Remaja di SMP Negeri 10 Manado. e-Kp Vol 6 No. 1

Astuti, Ponny. 2006. Meredam Bullying : 3 Cara Effektif Mengatasi Kekerasan Pada Anak

Baralemba, Adnan. 2018. Indahnya Beraneka. Yogyakarta : Deepublish

Carter, B. \& Vicky G. Spencer, 2006, The Fear Factor: Bullying And Students With Disabilities, International Journal Of Special Education. Vol. 21, Number 1.

Ela Zein, dkk. 2017. Faktor yang Mempengaruhi Remaja dalam melakukan Bullying. Jurnal Unpad. Vol 4 No. 2

Fithria, Rahmi Aulia. 2016. Factors Related to The Bullying Behavior. Idea Nursing Jurnal. Voll VII No. 3

Fraenkel, J.R dan Wellen, N.E. 2008. How to Design and Evaluate research in Education. New York: McGraw-Hill.

Masdin. 2013. Fenomena bullying Dalam Pendidikan. Jurnal Al-Ta'dib Vol 6 No. 2

Permendikbud. No 18 Tahun 2016 Tetang Pengenalan Lingkungan Sekolah Bagi Siswa Baru

Sejiwa. 2008. Bullying : Mengatasi Kekerasan di Sekolah dan Lingkungan Sekitar Anak. Jakarta : Grasindo

Sugiyono. (2007). Metode Penelitian Pendidikan: Pendekatan Kuantitatif, Kualitatif dan RnD. Bandung: Alfabeta.

Syamsuddin dan Vismaia S. Damaianti. 2009. Metodologi Penelitian Pendidikan Bahasa. Bandung: PT Remaja Rosdakarya.

Tim Sejiwa. 2008. Bullying: Panduan Bagi Orang Tua dan Guru Mengatasi kekerasan di Sekolah dan Lingkungan. Jakarta: Grasindo

http://referensi.data.kemdikbud.go.id

https://www.guru-id.com

https://www.kendikbud.go.id

https://news.detik.com 